\title{
Democratization
}

\section{Islamist moderation without democratization: the coming of age of the Moroccan Party of Justice and Development?}

\section{Eva Wegner \& Miquel Pellicer}

To cite this article: Eva Wegner \& Miquel Pellicer (2009) Islamist moderation without democratization: the coming of age of the Moroccan Party of Justice and Development?, Democratization, 16:1, 157-175, DOI: 10.1080/13510340802575890

To link to this article: https://doi.org/10.1080/13510340802575890

曲 Published online: 16 Feb 2009.

Submit your article to this journal $₫$

Џ Article views: 766

Q View related articles ¿

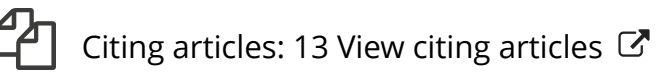




\title{
Islamist moderation without democratization: the coming of age of the Moroccan Party of Justice and Development?
}

\author{
Eva Wegner* and Miquel Pellicer \\ Mohammed V University, Rabat, Morocco
}

(Received 19 May 2008; final version received 20 October 2008)

\begin{abstract}
This article studies a novel factor relevant for the moderation of an Islamist party: the degree of dependency on a social movement organization. This question is examined in a case study analysing the evolution of the relationship between the Moroccan Islamist party, Party of Justice and Development (PJD), and its founding social movement organization. Over time, the PJD has been gaining autonomy, becoming more moderate and simultaneously gaining strength. Contemporaneously, liberalization in Morocco has been partially reversed, partly as a result of the rising Islamist strength. These findings suggest that it is the strength of the Islamist opposition, rather than its ideological rigidity, that makes MENA rulers reluctant to liberalize. We study the implications of these findings for European Union policy towards Islamist parties in the MENA region.
\end{abstract}

Keywords: Islamist parties; Morocco; moderation; authoritarianism

\section{Introduction}

The literature on democratic transitions has frequently argued that the moderation of oppositional actors is an important requisite for successful democratization processes. According to this literature, moderation is required to defuse the 'fear of the masses' of incumbent elites. This argument has been subsequently put into question by showing important, successful transitions where the opposition was far from moderate, such as in Portugal. ${ }^{1}$

In scholarship on the Middle East and North Africa (MENA), the moderation of the Islamist opposition has recently received considerable attention. ${ }^{2}$ As a leading scholar writes, Islamist moderation has emerged as 'the issue at stake in debates on Islamist political participation'. ${ }^{3}$ This literature focuses on whether the inclusion of Islamist organizations in the formal political processes leads to their ideological moderation. Moderation is typically defined narrowly as 'becoming truly committed to democratic practices'. ${ }^{4}$ Whether moderation is a requisite

${ }^{*}$ Corresponding author. Email: Wegner.eva@gmail.com 
for democratization in the MENA or not is rarely made explicit in this literature, although it often seems to be assumed implicitly. ${ }^{5}$ (In the following, we will refer to this literature as the 'inclusion-moderation literature'.)

Regardless of whether moderation is actually required for democratization or not, it appears to be relevant for Western decision-makers. In particular, the timidity of democracy promotion efforts by the European Union (EU), and Western actors more generally, towards the MENA is frequently attributed to the ideological nature of Islamist movements. To the extent that Islamists are not 'moderate', it is believed that pursuing an energetic democracy promotion policy could backfire by bringing to power actors that would hold illiberal and possibly anti-democratic and anti-Western positions ${ }^{6}$ (see Hovdenak's article on Hamas in this special issue).

This article studies the moderation of one strand of the Islamist opposition in Morocco and discusses implications more widely for EU policy toward rulers and the Islamist opposition in the MENA. In contrast to the inclusion-moderation literature, we do not focus particularly on Islamist positions towards democratic practices but define Islamist moderation as an increasing flexibility towards core ideological beliefs. We consider our definition more appropriate as it does not presume that Islamists are per se anti-democratic. Like the inclusion-moderation literature, we study the effect of inclusion on moderation: the constraints flowing from participation in formal political processes are supposed to promote bargaining, compromise, and the pursuit of small policy gains, all of which require that the content of the ideology is negotiable. We focus on a novel channel of moderation that relates to the interactions between an Islamist party and an Islamist social movement. We also examine, briefly, the implications of this moderation for political reform in Morocco.

A relevant, and often overlooked, characteristic of Islamist parties in the MENA is that, even when founded by an Islamist social movement organization (ISMO), they are distinct from these organizations. The evolution of a party's relationship with an ISMO affects the party's margin for political moderation. At least initially, a party depends on an ISMO's resources for mobilization and support. Being dependent, a party has to give voice to its founding organization's demands and policy stances. ${ }^{7}$ This is not contentious in the beginning, as both organizations share similar interests, mainly to increase protection from repression and to promote the Islamist agenda. ${ }^{8}$ However, while a party operates in the institutional arena, an ISMO does not and, therefore, is not subject to those institutional constraints that apply to political parties such as building coalitions and compromise with other political parties to advance their policy goals. In the hegemonic authoritarian regimes of the MENA, political parties, moreover, have constantly to signal loyalty to the regime and acceptance of its legitimacy to rule in order to avoid repression. As a social movement actor, an ISMO can thus typically afford to remain more committed to its core agenda. As a result of these different environments, electoral participation can lead to an increasing gap between the two actors' agendas: Over time, the priorities of party leaders and members 
may increasingly be dictated by the logics that rein in the institutional arena and by loyalty to a party rather than to a social movement organization. In this process, a party may reform or trade central programmatic points. ${ }^{9}$ This process, however, will be limited to the extent that the party maintains a strong dependency on the movement. Thus, the degree of dependency of a party on its founding organization is likely to be relevant for its margin for moderation.

Against this background, this article investigates the relationship between the Party of Justice and Development (PJD) and its founding organization, the Movement of Unity and Reform (MUR) in Morocco. The article covers the period from 1992, when the palace tolerated the integration of the Islamists into a dormant political party, up to 2007, when the latest parliamentary elections were held in Morocco. It focuses especially on the period from 1997-2004, when the emancipation process of the PJD from the MUR took place. The case study in this article is based on two field research trips, the first in 2003-2004, and the second in 2007. ${ }^{10}$ It shows that, over that period, the PJD became more independent and moderate partly by acquiring independent mobilization resources, and also stronger in terms of popular support. The article shows that the Moroccan regime responded to these developments by deliberalizing, suggesting that the regime cared more about strength of the Islamic opposition than its level of moderation.

Based on the case study, the last section of the article speculates about policy implications for actors who want to promote Islamist moderation and political liberalization in the MENA. It focuses on the consequences of providing resources to Islamist parties, for instance, by giving advice on professional electoral campaigning or, more generally, by publicly considering them as legitimate opposition actors. The actual policy of the EU towards Islamists in the MENA region is contrasted with the lessons extracted from the case study.

The article is organized as follows. The second section studies the growing autonomy of the PJD from the MUR. The third section analyses the PJD's moderation process, while the fourth examines the response of the regime to the increasing strength of the PJD. The fifth discusses the implications of our findings for EU policy towards Islamist parties, and the sixth section is the conclusion.

\section{The emancipation process of the PJD}

The PJD is the offspring of one of the two principal Islamist movement organizations in Morocco. ${ }^{11}$ Its inclusion occurred at a moment of political reforms, among them two constitutional reforms that attributed more power to political parties and parliament but did not affect the authoritarian nature of the political regime.

The Islamist organization which gave birth to the PJD emerged from the Islamic Youth Association, an organization founded around $1970 .{ }^{12}$ The founder of the Islamic Youth Association, Abdel Karim Muti', an inspector of the ministry of education, was influenced by the radical ideas of the second leader of the Egyptian Muslim Brotherhood Sayyid Qutb. ${ }^{13}$ Mirroring Qutb's beliefs about 
Egyptian society, Muti' considered Moroccan society to be in a state of pre-Islamic ignorance against which the use of violence was legitimate to achieve an 'Islamic state'. The Islamic Youth recruited its members mostly in universities and in secondary schools. After the implication of some members in the assassination of Omar Benjelloun, editor of the socialist party newspaper and prominent Moroccan Marxist intellectual, in 1975, the organization was banned and officially dissolved in 1976. Muti' fled into exile and was - in absence - condemned to a life sentence; the militants of the organization remaining in Morocco were persecuted.

The majority of the activists founded a new organization, al-Jama'a alIslamiyya (The Islamic Group) in 1981 (which became the MUR in 1996). Its founders Mohamed Yatim, Abdallah Baha, and Abdellilah Benkirane were later Members of Parliament and members of the General Secretariat of the Party of Justice and Development. Since the mid-1980s, a reformist vision and a comprehensive approach to society emerged and solidified within this organization. Violence as a means to achieve political goals was explicitly condemned; the political and religious legitimacy of the monarchic regime was officially accepted; and the organization adopted internal democratic structures. ${ }^{14}$

The Moroccan Islamists had thus already reformed their positions regarding the use of violence and democratic principles before participating in the political process. Other positions mirror those promoted by many Islamist groups in the Middle East and North Africa. According to a charter published in the late 1980s, the organization's goals were to renew the understanding of religion, to advocate the implementation of shari'a law, to achieve a comprehensive cultural renaissance, to work on accomplishing the unity of Muslims, to confront ideologies and ideas which they believed were subversive to Islam, and to raise the educational and moral level of the Moroccan people. These objectives were to be attained by individual, public, cultural, social, economic, political, and educational activities. $^{15}$

From the 1980s, the organization engaged in a discussion on the desirability and potential means of political participation. Different options for its implementation were considered. The preferred one, the creation of its own political party, was rejected by the authorities in 1992. Instead, the palace tolerated the taking over of a dormant political party (the Movement Populaire Constitutionnel Démocratique - MPCD) by leaders and members of the MUR. This arrangement was made official in 1996 at an extraordinary party congress of the MPCD, during which MUR leaders were appointed to the party's highest body, the General Secretariat. This party was renamed the Party of Justice and Development in 1998.

Initially the party depended strongly on the MUR for human, propaganda, and infrastructure resources. From the late 1990s onwards, the PJD slowly decreased its dependency on the MUR. An important precondition was that no formal links were established between the two organizations: party membership was not made conditional on MUR membership and no quotas for office were reserved for MUR members. In the late 1990s, MUR committees debated the question of a total fusion with the party, but eventually voted against it. ${ }^{16}$ The MUR's Shura 
Council then adopted a 'document of complementarity' that laid out the intended division of labour. The PJD was defined as a political organization dealing with all political issues of the country and defending 'Islamic causes' in the institutions, whereas the MUR was meant to focus on vocation/mission $\left(d a^{\prime} w a\right)$ and education. The two organizations were to be linked by consultation, co-operation, and co-ordination, and by their joint objectives and principles. ${ }^{17}$ From then on, their relation was labelled a 'partnership'.

The increasing distance between the two organizations materialized particularly along two dimensions: First, the PJD increased its independent mobilization resources, and, second, it established boundaries in relation to its environment through the institutionalization of the party organization. Independent mobilization resources consisted of financial and human resources, and ancillary organizations of the party. Financial resources were partly provided by the Moroccan state through funding of the party's electoral campaign. However, the party also raised money through the reallocation of at least $22 \%$ of the Members of Parliament's (MP) salary (which the party had made mandatory) and membership fees. ${ }^{18}$

Independent human resources were gained through new party members who were not affiliated to the MUR. By 2004, the PJD had increased its membership to between 12,000 and 15,000 members. ${ }^{19}$ While there is no way to assess directly the proportion of MUR members among these, we can infer a trend of a decreasing proportion of MUR members among PJD members from different types of data. First, a survey of party congress deputies from 2004 shows that one-third of them had joined the PJD after $1999 .{ }^{20}$ Knowing that the majority of MUR members initially interested in party politics joined the party between 1992 and 1999, we can assume that a large number of the newcomers were not affiliated to the MUR. Most likely, the proportion of newcomers was actually higher, since a survey from the party congress tends to be biased towards members with a higher degree of seniority. Second, by 2002, there was a large proportion of non-MUR members among the PJD's local and provincial party leaders, electoral candidates, and MPs. This was shown in the profiles of the PJD's 179 candidates for the 2002 parliamentary elections, published by the MUR's journal Al-Tajdid, which listed the candidates' affiliations with other organizations and their position in the party. These profiles show that among these candidates, only one-third of those who were part of the PJD's 'intermediate leadership' (National Council and/or members of the provincial secretariats) and only a quarter of those holding office in the PJD's local secretariats were also MUR members. For the PJD's candidates and deputies, this trend was even more marked. Out of the 179 candidates, only 56 were affiliated to the MUR. As for the MPs, out of the 42 MPs in 2002, only 22 were MUR members. ${ }^{21}$ This contrasts sharply with the profiles of the 14 deputies from 1997, who were all MUR members except for one. Finally, even some of the party members affiliated to the MUR may be best considered as PJD human resources. This proves to be the case, as will be shown below, since such members may shift their loyalty to the party. 
More independent resources also came from developing parallel structures to the MUR: a 'Commission for Women and the Family' and a youth organization, the 'Youth of Justice and Development'. Both of these can be regarded as competing organizations to the MUR's (much more powerful) Organization for the Renewal of the Female Conscience and its Youth committee, respectively. In contrast, the PJD's Forum du Développement, founded in 2002, has no MUR counterpart. It is a forum of cadres who are either members or supporters of the party. Its tasks are to develop party policies, to support the parliamentary group, and to give technical and political training to the party's deputies. These ancillary organizations are exclusively financed by the party.

By 2002, the PJD's independent resources for electoral mobilization had improved considerably in comparison to the 1997 campaign, for which the party had entirely relied on the MUR. This was even more the case for the elections in 2003. In the 2003 campaign for the communal elections, the PJD's national office aimed to co-ordinate and unify the local campaigns and provided the local sections with a remarkable amount of independent propaganda resources.

The second crucial step towards autonomy was the institutionalization of the PJD's party organization. In a general way, institutionalization implies the establishment of boundaries vis-à-vis the environment. ${ }^{22}$ For a party, these boundaries are particularly sharpened when rules are formalized and abided by, so that there is less scope for an informal impact of other organizations on the party. Moreover, institutionalization implies the strengthening of the role of the party organization for providing legitimacy to party leaders at all levels of the organizational hierarchy and, ultimately, to tie their loyalty and interests to the survival of the party rather than the movement organization.

In the case of the PJD, the formalization of party rules at all levels was consciously enacted through two revisions of the party's by-laws in 1999 and 2004. At the beginning, the competences and prerogatives of different party bodies were only loosely defined; in practice, electoral candidates were nominated by the party leadership and the latter was appointed rather than elected. The vagueness of the original by-laws - a rather obscure, one-page document - left much space for informal external influence. ${ }^{23}$ In contrast, the 2004 by-laws define the relationship and prerogatives of the different bodies in detail: complicated procedures apply for choosing the candidates both for parliamentary and local elections and for party office.

Moreover, a commitment to internal democratic practices, and the respect for procedures and their transparency enforced the effect of formalization on party autonomy. This commitment to transparency of procedures and to internal democratic structures, as part of the party's message and identity, has been relevant to the party since the late 1990s. For instance, at the opening session of the 1999 congress, Al-Mukri al-Idrissi Abu Zaid, a member of the General Secretariat, emphasized that a political party that did not respect its own rules could not protest against the state's lack of rule of law. ${ }^{24}$ As another party leader put it more recently, a rule can be more or less good, but the most important thing is that 
the rules for selection are clear and transparent and applied to everybody. ${ }^{25}$ In the same fashion, provincial secretaries cite the party rules to defend contested decisions vis-à-vis the base, for instance, regarding the selection of electoral candidates, ${ }^{26}$ and party members mention democracy and transparency as a reason for joining the party. ${ }^{27}$ Crucially, the very fact that the General Secretariat formalized an extension of its powers through the 2004 by-laws, instead of keeping the vagueness of its prerogatives, shows that 'democratic legitimacy' and transparency are highly valued in the PJD.

The combination of detailed decision-making procedures with the commitment for respecting these procedures worked as strong boundaries vis-à-vis the MUR, leaving little space for extra-organizational nominations and decisions. Indeed, the legitimacy of party leaders and party decisions now has an intra-organizational source. One example is the General Secretariat. Even if all the initial MUR architects of the political inclusion of the Islamist movement still hold office in the PJD's General Secretariat, this is not because they are appointed in their function as MUR leaders. Their legitimacy now formally emanates from being elected by the party members in the congress and the National Council, and party leaders are accountable to party institutions.

These developments may, ultimately, also shift the loyalty of office holders away from the MUR and towards the party. In the case of the General Secretariat, interviews revealed that, by 2003 , there were essentially three ways in which the current and former affiliation with the MUR was treated. First, there was a stronger loyalty to the MUR. Party activities and decisions were based on whether they were deemed beneficial or not for the MUR. ${ }^{28}$ A second way of addressing the issue was a sort of stated separation of loyalties, where the logic of action was seen as depending on the respective organizational context. ${ }^{29}$ In this case, it is not clear what would happen if conflicts arose between these two loyalties. Finally, in some cases, the commitment to the party clearly took precedence. An example of this came from a member of the General Secretariat who had given up his MUR office position. He treated his MUR affiliation as similar to his affiliation with a labour union and his presidency of a study association. In his words, he was 'a member of many things'. ${ }^{30}$

In sum, the PJD has increased its autonomy considerably since its first electoral participation in 1997. This was a consequence of the strengthening of the party's independent capabilities for mobilization and of changing the structural characteristics of the party organization to decrease the informal impact of the MUR on an initially weak organization which had no clearly defined boundaries. It is noteworthy that - except for the automatic state funding - all these were deliberate decisions of the party leadership. This is telling for how the party viewed itself. Had it been content with simply being the parliamentary branch of the MUR, there would have been no need for the party to have its own organizations linking it to social groups, no need for independent human resources, nor to invest so much in the party organization. Initially, this investment in the party organization is likely to have resulted from the MUR's illegality as it 
increased the benefits of investing in the legal structures. However, even after the legalization of the MUR, the PJD's investment in mobilization capabilities and party institutionalization continued at the same, if not greater, pace. ${ }^{31}$

\section{Party autonomy and moderation}

The PJD's gradual autonomy from the MUR facilitated an increasing flexibility of the party vis-à-vis their previously shared agenda. Generally, party autonomy facilitates such flexibility, as no extra-institutional actor can enforce its positions on the party. As mentioned above, the key difference between party and social movement organization is that the former operates under the constraints of formal politics, whereas the latter does not. As long as the movement organization, as an extra-institutional actor, controls the party, the moderation of the party is either impossible (in case of total dependency), or too costly from a support point of view. Thus, moderation is only possible to the extent that the party has sufficient autonomy or that the movement organization endorses moderation itself, as a result of other factors.

We operationalize moderation as stemming from institutional constraints by comparing the attitude of the PJD and of the MUR towards different decisions of the PJD that involved compromise on the Islamist agenda. Thus, we use the degree of disagreement/conflict between the two actors as an indicator of the party's moderation. In the following, we discuss party decisions and MUR attitudes regarding the support of, or the participation in governance with, left parties, the rise of technocrats in the party, and the policies implemented by PJD local councillors to assess the party's moderation over time.

Indeed, in the early years of the PJD's parliamentary presence (1997-1999), when the party was fully dependent on the MUR, no conflicts appear to have occurred. ${ }^{32}$ The initial support the PJD lent to the Left-led alternance government in 1998 was supported by the MUR as a necessity for consolidating former King Hassan II's toleration of the Islamists' electoral participation. Everyone wanted to show that the Islamists were not a 'current of refusal' but a constructive and conciliatory movement that supported the King's decision to form a consensual government. ${ }^{33}$

In 2000, the first problems materialized in the context of this support. The alternance government aimed to modernize the Moroccan personal status code (family laws). Supporting the government, the PJD would have had to endorse a bill that the MUR (in fact, the entire Moroccan Islamist movement) strongly opposed and had mobilized against since the spring of 2000. The Islamists mainly opposed the abolition of polygamy and the right of women to arrange marriages without a 'marital tutor'; but the protest was also conducted as a general campaign against the 'secularist and francophone elites' and 'foreign powers' which supported the project in order to strip the country of its Islamic identity and heritage (see also Powell's article on Tunisia in this special issue). Moreover, this occurred in the context of another ideological conflict about a 
bill on micro-credits, where the government refused an amendment the PJD wanted to introduce. This amendment provided the possibility of introducing Islamic modes of financing, that is loans without interest, alongside conventional means of financing. From the PJD's perspective, the Islamist mobilization against a government it supported posed heavy problems. Eventually, its National Council voted in favour of going over to the opposition in autumn 2000, thus bringing the party in line with the Islamist agenda. However, it is noteworthy that the vote in the National Council was very narrow. The decision against further support of the government was taken with a difference of only 11 voices out of 280 , showing already a decreasing, ideological rigidity of many representatives of the intermediate leadership. ${ }^{34}$

After the 2002 parliamentary elections, the issue of cabinet participation was again raised. The PJD had increased its seats from 14 to 42 and would have obtained around six to seven ministries if it had joined government. ${ }^{35}$ The MUR's concern that that the PJD would join an 'un-Islamic' government were publicly expressed by the MUR's president. About one month after the elections, while the discussion about the constitution of the government was underway, Ahmed Raissouni, the MUR's president from 1998 to 2003, gave an interview to the PJD's newspaper Al-'Asr. In this interview, he claimed the PJD's electoral success for the MUR, stating that 'The reputation of the party and its popularity are the fruit of this movement [the MUR], which directed all its efforts and its activities towards this party'. ${ }^{36}$ Additionally, while saying that he did not speak 'in the name of the party', Raissouni issued conditions for cabinet participation: $\mathrm{He}$ 'could not imagine' that the party would participate in a government that did not clearly engage itself in respect of the Islamic identity of the country and the reinforcement of the Arabic language. In particular, he stated that the party should refuse to participate in a government which rejected the establishment of zakat (obligatory alms) and loans without interest. In view of the aforementioned profiles of the PJD's deputies from 2002, Raissouni's concerns about the PJD's betrayal of the Islamic cause were probably somewhat justified. By linking a reminder about the PJD's dependency to advice about acceptable and nonacceptable conditions of cabinet participation, Raissouni intended to define thresholds of compromise for the party and to make the party adhere to the Islamists' core ideology. The very fact that this reminder had to be made via public channels, however, also indicated clearly that, by 2002, the MUR was not able to control the party directly.

That the PJD did not join the cabinet in 2002 was certainly an acknowledgement of the MUR's threat. At the same time, it is noteworthy that the party had also strong, non-ideological incentives not to join the cabinet and that those party leaders and MPs who were against cabinet participation seldom mentioned ideological reasons for not joining the cabinet. Rather, they feared a decrease in future electoral strength caused by being part of a government that was unlikely to improve the socio-economic grievances of those new voters whose support it had gained in the elections. Along the same lines, party leaders were aware that 
cabinet participation would make it more difficult to maintain its image as noncorrupt challengers of the Moroccan elite. Therefore, joining government would have come at the price of losing not only the MUR's support, but also that of new sympathizers who had voted for the party in the 2002 elections. Moreover, just as in 2000, the decision to join the opposition benches was far from being unanimous among party members and leaders. There were essentially three reasons given by those wanting to maintain support for the government in 2000 and those wanting to join it in 2002. A first group feared that the PJD would increase its electoral strength in opposition and, thus, scare the regime. A second and a third either saw no crucial programmatic differences between the PJD and the other Moroccan parties', maintaining that ideological policies were a luxury that could be promoted once the basic work was done (that is, decrease poverty, etc.), or wanted to acquire more governmental expertise for the future. ${ }^{37}$

After the 2003 municipal elections, the PJD changed its attitude towards government. As already mentioned, the PJD had organized its electoral campaign independently and made use of its own (new) propaganda resources in these elections. After the elections, the party formed local governmental alliances with all the existing Moroccan parties. This very pragmatic approach towards local government was the consequence of a clear orientation of the party leadership towards institutional politics and their appreciation of what this required. Most importantly, the leadership's decision was due to its perception that - after the terrorist attacks of 16 May 2003 - the PJD should demonstrate through participation in government that it was not 'a party of refusal' ${ }^{38}$ At that time, the PJD also tried to distance itself more clearly from the MUR and denounced MUR leaders for speaking in the name of the party. ${ }^{39}$ an obvious hint to MUR leader Ahmad Raissouni, who had restated his rejection of government participation with the left and, moreover, questioned the King's ability to fulfil his role as Commander of the Faithful. ${ }^{40}$

A second perspective where we can see how the increasing distance from the MUR allowed institutional considerations to dominate party decisions, can also be found in the context of the 2003 communal elections. After 16 May, the power of a pragmatist, technocratic faction inside the General Secretariat and the National Council grew considerably. A prominent representative of this faction was a leading member of the party's ancillary organization, Forum du Développement. While a MUR member, he became fully absorbed with institutional considerations for policy-making: For example, he argued that it was too easy to denounce the government for privileging the macro-economic equilibrium when this was a constraint imposed by international actors. Moreover, he strongly criticized the Islamists' inclination to populism and unrealistic policy promises for winning 'the crowd's' support and stressed the necessity of a 'culture of expertise and of figures' and feasible policy propositions that were 'scientifically valid'. ${ }^{41}$

Importantly, the increasing power of the technocrats among the leadership allowed them to implement an idea they had previously pursued unsuccessfully during the 2002 parliamentary elections: to bring the party's cadres from the 
back row into the centrality of politics. Technocrats were 'parachuted' into electoral lists' pole positions. From the perspective of the party leaders, the technocrats were to provide the living evidence of the PJD as a party of serious and conciliatory people who knew how to deal with a budget and deliver improvements, and who could establish good relations with the authorities.

The following example of a PJD vice-mayor illustrates how these experts approach politics in the framework of local governance. The vice-mayor pursued concrete projects, the implementation of which he favoured over faithfulness to Islamist ideology. Immediately after his appointment, this vice-mayor drafted a project for social housing to improve the living conditions in the poorest neighbourhoods. After overcoming the initial suspicion of the mayor and the governor, his project was set in motion. It was financed through loans with interest. Acknowledging the contradictions with the Islamist claim against usury the very claim that, as shown before, was a no-go for the MUR's president he stated: 'I don't even realize, for me that's fine, this is not really what we are concerned about.' Clearly, he accepted this type of financing as a necessary condition, knowing that, otherwise, the project would not materialise at all. In his words: "Now, we realize that it is not enough to have principles to be able to set up a budget. The citizens judge you on the basis of your efficiency. ${ }^{42}$

This is, of course, only one example and not all those elected in the communal elections have the same profile. However, given the strong intervention of the General Secretariat in favour of the experts in the communal elections, and the fact that this faction is now dominating the General Secretariat, we suggest that this approach reflects a more general trend. Moreover, the increasing involvement in local governance has also begun to have an impact on those without a technocratic profile. The PJD's councillors reportedly started to get interested in advice regarding taxes, budgets, street lighting, waste, etc. ${ }^{43}$

In summary, as party autonomy grew, the PJD was increasingly capable of taking independent decisions that revealed a pragmatic attitude towards the Islamist agenda. Whereas in 2000 and 2002, the MUR's position won over the party, this was no longer the case in 2003. Of course, the institutional pressure on the party increased considerably after the terrorist attacks of May 2003. Nevertheless, autonomy is what enabled the party to respond to this pressure by only considering its own interests, even dropping key aspects of the Islamist agenda where necessary. Eventually, the MUR withdrew its support for the PJD, possibly the strongest indicator of the extent of the PJD's moderation over the last decade. Whereas in 2002, the MUR had aimed to bring the PJD in line by threatening to cut its support, in 2007, the support was actually cut. In the 2007 elections, there was no campaign on the PJD's behalf, not even an endorsement to vote for it. ${ }^{44}$

\section{Islamist moderation and deliberalization}

As shown above, the PJD became more and more ideologically flexible during the last decade. Not fully explicitly but unmistakably, many studies assume that 
Islamist moderation will make democratization in the MENA more likely. Although the mechanism by which this process is supposed to take place is not analysed, the assumption appears to be that Islamists' moderation would deflate fears of the political elite that Islamists would abuse democratic processes to install an Islamist dictatorship. ${ }^{45}$

In contrast, the PJD's moderation was not followed by a notable increase in civil and political liberties. On the contrary, since the beginning of the 2000s, there has been a trend towards reversing earlier political liberalization measures. This was shown in a more repressive approach, first, towards more critical social and political actors in general and, second, towards the PJD in particular.

An important symbol of the general trend towards deliberalization was the reversal of the newly acquired principle of nominating a political prime minister, that is, the head of the strongest party. Instead, Mohamed VI, who had followed Hassan II on the throne in 1999, nominated Driss Jettou, the previous minister of interior without party affiliation. Besides this, human rights abuses increased and press freedom decreased. For example, a 2004 report by Amnesty International highlighted Morocco's poor record, denouncing a sharp rise in reported cases of torture or ill-treatment in the context of 'counter-terrorism' measures from $2002 .^{46}$

As for the PJD, the regime increasingly intervened in party affairs, especially after 2003. First, the regime tried to neutralize the PJD's more critical figures, especially the outspoken head of the PJD's parliamentary group and member of the General Secretariat, Mustapha Ramid. In July 2003, Ramid had already offered his resignation in protest against the 'anti-democratic ways in which the party was treated and the odious instrumentalization of the May 16th attacks' ${ }^{47}$ At that time, the party leadership refused to accept his resignation. However, in October 2003, the minister of interior increased the pressure and Mustapha Ramid eventually had to resign as head of the parliamentary group. ${ }^{48}$ In the same vein, it was made clear to the leadership that Ramid must not become the party's Secretary General. ${ }^{49}$ Second, the PJD was forced to reduce its coverage of electoral constituencies in an unprecedented way in 2003. Originally, the PJD had intended to cover around $50 \%$, just as in the 2002 parliamentary elections. In the 2003 elections, however, after some 'negotiations with the ministry of interior ${ }^{50}$ the party was only allowed to contest around $18 \%$ of the contested seats. Moreover, a system of partial coverage was enacted. That is, in big cities, the constituencies were covered in such a way that the party could not win a majority of the seats, i.e. the presidency, in any city. Although the PJD could cover all constituencies in the 2007 parliamentary elections, strong gerrymandering and a new electoral law guaranteed that, while the PJD won most votes, it gained five seats less than the winning Istiqlal party.

Why did the regime repress an ever more moderate PJD? An important factor was certainly the increase in the PJD's strength. Since its first electoral participation in 1997, the PJD had increased its electoral support from 14 to 42 seats in 2002. Although in 2007 the PJD ultimately only gained an additional five 
seats, it was widely believed before the elections that it would gain up to $40 \%$ of the vote. ${ }^{51}$ In Morocco, where governments are typically composed of around five parties that fight over resources and ultimately resort to the King for arbitration, gaining $40 \%$ of the votes might have allowed the PJD to lead a small government coalition and to assert the prerogatives of party government, parliament, and political parties vis-à-vis the monarchy. If an elected government is assertive and defends its prerogatives, it is uncomfortable for the regime, irrespective of the policies pursued by any particular party. However moderate the PJD might have been in office, for the regime, a party with such strength would have hampered the pursuit of divide-and-rule politics, an important pillar of regime stability in Morocco. Even if - in contrast to the MENA republics - the electoral landslide of an oppositional party is not an immediate threat to regime survival, an important pillar of rule in MENA monarchies is precisely the division and fragmentation of political forces, which facilitate the control and manipulation of the opposition and allow the monarch to act as the supreme arbitrator of politics. ${ }^{52}$ The supremacy of the monarchy in the political game is thus based on the absence of a united opposition or one particularly strong oppositional actor. Moreover, the very fact that the Moroccan king has kept such tight control in the past over who would be allowed representation in the institutions (and in what proportion) demonstrates a strong concern about the balance inside these institutions.

In sum, any possible effect of the PJD's moderation on democratization was cancelled out by its increase in strength that was threatening the regime (for this point, see also Cavatorta's contribution in this issue).

\section{The EU and the promotion of Islamist moderation}

The promotion of democracy is a stated goal of the EU's external policies in general, and of the Barcelona process in particular. ${ }^{53}$ Although the EU has yet to develop a systematic approach towards Islamist parties, in view of European concerns about terrorism and radicalization, it is logical to assume that Islamist moderation and inclusion in the political process ought to be an EU goal as well. Moreover, an - admittedly awkward - illustration of the goal of moderation is the EU's stance towards the electoral victory of Hamas in January 2006 (see also Hovdenak's and Pace's contributions in this special issue on Hamas and EU democracy promotion). The three conditions that the EU, alongside the government of the USA and the United Nations (UN), established for recognizing the Hamas government (recognition of Israel, renunciation of violence, and acceptance of existing peace accords) can be understood as an - unsuccessful attempt to force moderation.

Besides showing that the EU indeed needs a policy towards Islamist political parties, an important lesson of this failed policy towards Hamas is that Islamist moderation cannot be mandated by an external actor. This applies particularly to actors such as the Islamists, who derive part of their legitimacy from their autonomy from Western influence. Thus, the EU, as an external actor, can be thought to 
have relatively little, direct influence over moderation processes and should seek to influence such processes indirectly.

Our case study suggests that one way of doing so could be through the provision of resources to Islamist political parties. A key implication of the Moroccan case is that an increasing pragmatism of Islamist parties can result from an increase in party autonomy from the Islamist movement and that this autonomy was fostered by the party's accumulation of its own resources. Drawing on the findings of the Moroccan case study one could speculate that external actors could contribute to these processes by providing resources to the party, for instance, by offering technical training to MPs and party members, improving their campaigning skills or, more generally, by publicly considering them as part of the legitimate opposition.

Whether the EU would see this channelling of resources to Islamist parties as beneficial or not is likely to depend on how moderate the party already is. The EU would probably not wish to empower a party if it considers it 'radical' in the first instance. If, conversely, the party is already moderate, empowering it would seem to be in the EU's interests, in the same way that it would typically seek to strengthen civil society actors in authoritarian regimes countries. ${ }^{54}$

This could be done by emulating the example of the United States. The US government-funded National Democratic Institute, for instance, provides training for Moroccan parties - including the PJD. Such a policy should be complemented by pressures for political liberalization to ensure that the regime does not respond to the Islamists' increasing strength with repression. Particular attention should be paid to preventing the party from being banned, as this would, at the very least, neutralize the gains of moderation. For the EU, including the PJD in civil society forums in the context of the Euro-Mediterranean Partnership (EMP), would officially recognize the party as a legitimate actor, thereby working as a shield against repression, and making it more difficult for the party to be banned.

Current EU policy towards Morocco shows a different picture. EU policy towards the Islamists - to the extent that it exists - is one of avoidance. Islamists have never benefited from funding in the framework of the EMP. In view of the PJD's legality, this would, however, be possible. Moreover, the agenda of the PJD is to some extent close to the EU's in that it promotes transparency, aims at upgrading representative institutions, and even promotes women in public and party office more energetically than the majority of the other Moroccan parties. However, the consensus among EU policy-makers appears to be to avoid the Islamist issue for as long as possible. In contrast, the EU strongly supports the Moroccan regime with material and legitimacy resources. To date, Morocco is one of the main benefactors among southern countries of the EMP. ${ }^{55}$ As to legitimacy resources, the EU provides them, for instance, with praise for the Moroccan 'democratisation process [and] transparent and democratic general elections' at a time when NGOs report deliberalization. ${ }^{56}$ Similarly, 
the renewed praise for the 2007 elections as 'democratic, transparent, and fair' by the EU and its member states stands in sharp contrast to an actual turnout of $37 \%$, and an electoral law designed to ensure the supremacy of the monarchy in the political process.

\section{Concluding remarks}

This article has focused on only one particular channel for moderation autonomy - which is surely not the only relevant one. However, as our case study showed, this channel can be important and its implications are undoubtedly worth considering seriously. These implications will obviously apply best for the Moroccan case. Nevertheless, we believe that the channel uncovered is of some generality and could potentially apply to other places as well. In that case, of course, the particular context needs to be taken into account.

There are important cases (for instance, Egypt) where the regimes refuse to legalize an Islamist political party and Islamists, thus, contest elections as independent candidates. In such cases, obviously our suggested path to moderation could not be set in motion. Those representing the party inside the political institutions will always be fully subject to the decisions of external leaders. In such cases, the EU's efforts could then be directed towards pressurising the regime for party legalization.

Party legalization may not in all cases lead to party autonomy as smoothly as was the case with the PJD. For instance, our research suggests that all the crucial decisions of the Jordanian Islamic Action Front (IAF) are, 15 years after its foundation, in reality taken by the Muslim Brotherhood. In this case, however, the social movement organization formalized its control over the party through a document that obliges IAF members who are members of the Muslim Brotherhood to vote for decisions previously taken by the IAF's Shura Council. ${ }^{57}$ Nevertheless, a faction inside the IAF is currently striving for more autonomy, namely through the recruitment of new members who are not affiliated to the Muslim Brotherhood. In some situations, therefore, certain conditions may make the evolution towards autonomy slower or more difficult, relative to the Moroccan case.

Finally, our article shows that moderation does not automatically lead to a greater willingness of ruling elites to democratize. Indeed, an ideologically flexible opposition is not enough to induce autocrats to democratize. Nancy Bermeo shows that moderation is not a necessary condition for democratization. ${ }^{58}$ Our case study shows that it is not sufficient either. For the EU, this implies that if moderation and democratization are relevant goals in the MENA region, each will have to be promoted for its own sake.

\section{Notes}

1. See Nancy Bermeo's discussion of the literature in her article 'Myths of Moderation'.

2. See, for instance: Clark, 'The Conditions of Islamist Moderation'; Schwedler, Faith in Moderation; Robinson, 'Can Islamists be Democrats?'. 
3. Schwedler, 'Democratization, Inclusion and the Moderation of Islamist Parties', 59, emphasis in the original.

4. See Schwedler, Faith in Moderation, 149.

5. Clark, for instance, writes that 'questions concerning whether the inclusion of Islamist political parties is leading to their ideological moderation and, as a result, the deepening of democracy, have become important and expanding areas of study in the literature on the Middle East' ('The Conditions of Islamist Moderation', 541). More generally, the fact that moderation is defined in relation to democratic practices and that its importance is motivated by the 'paradox of democracy' whereby possibly non-democratic actors may subvert democracy suggests that the Islamists' ideological rigidity is indeed perceived as a barrier for democratization in the Middle East. See Schwedler, Faith in Moderation, chapter 1.

6. Youngs, 'The European Union and Democracy Promotion in the Mediterranean'; Jünemann, 'Support for Democracy or Fear of Islamism?'; Sharp, 'US Democracy Promotion in the Middle East'.

7. For the implications of such an 'external sponsor' of a political party, see Panebianco, Political Parties: Organization and Power.

8. There are some issues that are typically part of the agenda of Islamist groups, such as the promotion of conservative morals, of personal status laws that are in line with supposed Qu'ranic principles, and of shari'a law. In accordance with the vagueness of the religious texts on which Islamist groups draw, the actual content of the ideology of Islamist parties or movement organizations as well as the role ascribed to shari'a is not immutable and varies across organization, country, and time. For a good overview of variations of Islamist ideology, see Krämer, Gottes Staat als Republik.

9. Of course, this development may not apply in all cases: some social movements may eventually become more moderate while some of these parties may never do so. The history of other social movement parties in general, however, shows that the large majority of such parties eventually drop a fundamentalist, ideologically driven agenda. See, for instance, Offe, 'Reflections on the Self-Transformation of Movement Politics', or Hanagan. 'Social Movements'.

10. The 2003-2004 field research was carried out by Eva Wegner; field research in 2007 was undertaken by both authors.

11. The other strand is Sheikh Yassine's Justice and Charity organization (al-'Adl wal-Ihsan). This organization is barred from participation in political institutions. Its exclusion is 'self-chosen' as it refuses the conditions of political participation: to accept both the religious legitimacy of the monarchy and its dominant role in politics.

12. The dates given for the founding of the Islamic Youth Association range from 1969 to 1972.

13. Sayyed Qutb (1906-1966) is considered one of the most influential Islamist theorists and activists in the twentieth century. In the 1950s and 1960s, he became the mastermind of the Egyptian Muslim Brotherhood. He is especially known for his view of Islam as a general religious, moral, social, and political system in his book Mile Stones in 1964. According to Qutb, shari'a is supposed to be the sole base of government and social relations in an 'Islamic state'. Accordingly, Qutb rejected the extant Arab regimes and advocated not only proselytizing and exemplary behaviour but also violence to achieve the true Islamic society. He was sentenced to death in 1966.

14. For the history of the Movement of Unity and Reform, see Tozy, Monarchie et Islam politique au Maroc.

15. The charter is cited in Shahin, Political Ascent, 189.

16. Al-Tajdid, Special Issue on the Movement of Unity and Reform (December 2002), 4.

17. Ibid., 16. 
18. The party received four million dirhams for the 1997 elections, $17 \mathrm{~m}$ dirhams for the 2002 elections, and another 4m dirhams for the 2003 communal elections (figures provided by the PJD's treasurer). The membership subscription is collected once a year. Working members (those who have been active for more than one year and have the right to vote in the party's internal elections) pay 200 dirhams (around $€ 20$ ). Participating members (those who have just joined to the party and still have to prove their commitment) pay 100 dirhams (around $€ 10$ ).

19. While it was impossible to get precise figures, these were given by party leaders during author's interviews with members of the PJD's general secretariat, Rabat, 4 September 2003 and 17 November 2003.

20. Data collected at the PJD's party congress in 2004. See Wegner, The Inclusion of Islamist Movements. Data is available from the authors upon request.

21. Profiles published daily in Al-Tajdid from 12 to 26 September 2002. Data available from the authors upon request.

22. Panebianco, Political Parties: Organization and Power.

23. The 1997 by-laws were published in the PJD's newspaper Al-'Asr, 10 October 1997, 4.

24. Al- Tajdid, Editorial, 'The PJD and the Present Responsibilities', 1 December 1999, 1.

25. Author's interview with member of the PJD's general secretariat, Rabat, 12 December 2003.

26. Author's interview with member of a PJD local secretariat, Khenitra, 9 November 2003 .

27. Author's interviews with delegates at the PJD's party congress, Rabat, 8-11 April 2004.

28. Author's interview with a member of the PJD's general secretariat and the MUR's executive bureau, Rabat, 12 November 2003.

29. Author's interview with a member of the PJD's general secretariat and member of the MUR's executive bureau, Rabat, 17 November 2003.

30. Author's interview with a member of the PJD's general secretariat, Rabat, 4 September 2003.

31. See Wegner, The Inclusion of Islamist, chapter 3.

32. In the 1997 parliamentary elections, the PJD covered around $50 \%$ of the electoral districts and won nine (out of 325) seats. In the autumn of 1999, after by-elections and the defection of two MPs from other parties, the figure increased to 14. According to the US Embassy's Country Report on Human Rights Practices, most independent observers concluded, however, that the 1997 election results were heavily influenced, if not predetermined, by the government. In the more transparent 2002 elections, the PJD covered again around half of the electoral districts and increased the number of seats to 42 (out of 325). In 2007, the party covered all districts except one and won 47 seats.

33. Author's interview with a member of the PJD's general secretariat, Rabat, 7 March 2003.

34. At that time, the National Council was composed of the PJD's MPs, the General Secretariat, and the leaders of local and provincial secretariats.

35. This is calculated on the basis of the number of ministers allocated to parties with similar electoral results.

36. Al-'Asr, 7 November 2002, 5, author's translation.

37. Author's interviews with PJD MPs and party leaders, Mohammedia and Rabat, 1 March 2003, 9 November 2003; 12 November 2003, 11 December 2003.

38. Author's interview with a member of the PJD's general secretariat, Rabat, 4 September 2003 .

39. Interview with Abdelilah Benkirane, member of the general secretariat and former MUR leader, La Vie Économique, 16 June 2003. 
40. Aujourd'hui Le Maroc, 12 May 2003, 1.

41. Author's interview, Rabat, 6 November 2003.

42. Author's interview, Rabat, 12 April 2004.

43. Conversation with a member of the PJD's Forum for Development at the party congress, Rabat, 8 April 2004.

44. Authors' interviews with PJD leaders, Rabat, 1, 2, and 3 November 2007.

45. For an illustration of this, see Schwedler, Faith in Moderation, chapter one, Schwedler, 'Democratization', and Clark, 'The Conditions'.

46. Cf. http://www.amnesty.org/en/library/asset/MDE29/004/2004/en/dom-MDE 290042004en.html

47. Al-Ayam, 18 July 2003, 1.

48. See, Le Journal Hebdomadaire, 7-13 December 2003, 1-2.

49. Author's interview with a PJD member, Rabat, 12 April 2004.

50. Author's interview with a PJD leader, Rabat, 12 November 2003. The party later portrayed the reduction of the coverage as its own, autonomous decision. See Wegner, 'Islamist Inclusion and Regime Persistence'.

51. At the time of writing, it is not clear whether the weak result of the PJD (as compared to the expectations) was the outcome of vote-buying - as claimed by the PJD - or of weaker electoral support for the PJD than expected. Whatever the truth, for our argument, it is not the result as such that matters, but what everybody believed before, namely that the PJD would be by far the strongest party after the elections.

52. Richards and Waterbury, A Political Economy of the Middle East, 297-98.

53. See the EU's external relations' website at http://ec.europa.eu/external_relations/ human_rights/intro/index.htm, and for the 1995 Barcelona declaration, see http:// ec.europa.eu/external relations/euromed/index en.htm

54. See Wegner, 'Authoritarian King and Democratic Islamists'.

55. For EU policies towards Morocco, see among others, Haddadi, 'The EMP and Morocco' and Haddadi 'Two Cheers for Whom?'.

56. See European Commission, 'Euro-Med Partnership: Morocco. National Indicative Programme 2005-2006', June 2004, 1.

57. Interview with a member of the IAF's executive bureau, Amman, 14 June 2007.

58. Bermeo, 'Myths of Moderation'.

\section{Bibliography}

Bermeo, Nancy. 'Myths of Moderation: Confrontation and Conflict during Democratic Transitions'. Comparative Politics 29 (1997): 305-22.

Clark, Janine A. 'The Conditions of Islamist Moderation: Unpacking Cross-Ideological Cooperation in Jordan'. International Journal of Middle East Studies 38 (2006): 539-560.

Haddadi, Said. 'The EMP and Morocco: Diverging Political Agendas'. Mediterranean Politics 8 (2003): 73-89.

Haddadi, Said. 'Two Cheers for Whom? The European Union and Democratization in Morocco'. In The European Union and Democracy Promotion: The Case of North Africa, ed. Richard Gillespie and Richard Youngs, 149-69. London: F. Cass, 2002.

Hanagan, Michael. 'Social Movements. Incorporation, Disengagement, and Opportunities A Long View'. In From Contention to Democracy, ed. Mario G. Giugni, Doug McAdam, and Charles Tilly, 3-30. Lanham, MD: Rowman \& Littlefield, 1998.

Jünemann, Annette. 'Support for Democracy or Fear of Islamism? Europe and Algeria'. In The Islamic World and the West: An Introduction to Political Cultures and International Relations, ed. Kai Hafez, 103-26. London: Brill Academic Publishers, 2000 . 
Krämer, Gudrun. Gottes Staat als Republik. Baden Baden: Nomos, 1999.

Offe, Claus. 'Reflections on the Self-transformation of Movement Politics: A Tentative Stage Model'. In Challenging the Political Order. New Social and Political Movements in Western Democracies, ed. Russell J. Dalton and Manfred Kuechler, 232-50. Cambridge: Polity Press, 1990.

Panebianco, Angelo. Political Parties: Organization and Power. Cambridge: Cambridge University Press, 1988.

Richards, Alan, and John Waterbury. A Political Economy of the Middle East. 2nd ed. Boulder, CO: Westview Press, 1998.

Robinson, Glenn E. 'Can Islamists be Democrats? The Case of Jordan'. Middle East Journal 51 (1997): 373-87.

Schwedler, Jillian. 'Democratization, Inclusion and the Moderation of Islamist Parties'. Development 50 (2007): 56-61.

Schwedler, Jillian. Faith in Moderation. Islamist Parties in Jordan and Yemen. Cambridge: Cambridge University Press, 2006.

Shahin, Emad Eldin. Political Ascent. Contemporary Islamic Movements in North Africa. Boulder, CO: Westview Press, 1998.

Sharp, Jeremy. 'US Democracy Promotion in the Middle East: The Islamist Dilemma'. CRS Report for Congress RL33486 (2006).

Tozy, Mohamed. Monarchie et Islam politique au Maroc. Paris: Presses de Sciences Po, 1999.

US Department of State. Morocco Country Report on Human Rights Practices for 1998. http://www.usembassy.ma/themes/CivilSociety/us.htm

Wegner, Eva. 'Authoritarian King and Democratic Islamists in Morocco'. The Challenge of Islamists for EU and U.S. Policies: Conflict, Stability, and Reform, ed. Daniel Brumberg and Muriel Asseburg, 53-8. Washington/Berlin: USIP/ SWP, 2007.

Wegner, Eva. 'The Inclusion of Islamist Movements Into Political Institutions: The Case of the Moroccan Party of Justice and Development'. European University Institute, 2006, $\mathrm{PhD}$ thesis.

Wegner, Eva. 'Islamist Inclusion and Regime Persistence: The Moroccan Win-Win Situation'. In Debating Arab Authoritarianism: Dynamics and Durability in NonDemocratic Regimes, ed. Oliver Schlumberger, 75-93. Stanford: Stanford University Press, 2007.

Youngs, Richard. 'The European Union and Democracy Promotion in the Mediterranean: A New or Disingenuous Strategy?'. Democratization 9 (2002): 40-62. 